\title{
THE EFFECTIVENESS OF DUNALIELLA SALINA AGAINST THE DECREASE MACRONUCLEI AND MICRONUCLEI OF HYBRID GROUPER (EPINEPHELUS FUSCOGUSTATUS X EPINEPHELUS LANCEOLATUS) INFECTED BY IRIDOVIRUS
}

\author{
Yuwanita Rani, Buwono Nanik Retno, Ating Yuniarti, Lecturers \\ Priambodo Rana, Student \\ Faculty of Fisheries and Marine Sciences, University of Brawijaya, Indonesia \\ ${ }^{*}$ E-mail: raniyuwanita@ub.ac.id
}

\begin{abstract}
Cultivation of hybrid groupers (Epinephelus fuscogustatus $\times$ Epinephelus lanceolatus), is one of the fish farming activities that have high economic value. Lately the existence of Iridovirus has become a big problem for cultivation. It was a deadly viral disease for grouper hatchery in Asia including Indonesia. Iridovirus may cause mass mortality, especially larvae up to fingerling size. The purpose of this study was to determine the effect of different level of Dunaliella salina against the decrease the number of micronuclei and macronuclei of hybrid grouper. As many as 180 seeds of hybrid grouper with weight 4-5 gram disperse into 15 tanks volume of 16 litres with density of 10 fish/tank. Four treatments were applied with different diets containing powder of Dunaliella salina of K- $\left(0 \mathrm{gr} \mathrm{kg}^{-1}\right.$ diet fed), A (2 gr $\mathrm{kg}^{-1}$ diet fed), B (4 $\mathrm{gr} \mathrm{kg}^{-1}$ diet fed) dan C (6 gr kg${ }^{-1}$ diet fed), with three repetition. Experimental diet was given twice for 10 days. After 10 days of treatment, the fish tested challenge with Iridovirus for 96 hours. The main parameters observed in this study were the number of micronuclei and macronuclei. Based on the research, most of the hematological parameters such as erytrocitess, $\mathrm{Hb}$ and HE significantly increased in Dunaliella salina-treated fish compared with controls $(P<0.05)$. Micronuclei and macronuclei after challenge with Iridovirus in $6 \mathrm{mg} / \mathrm{kg}$ Dunaliella salina-treated fish was $10.57-14.58 \mathrm{MN} / 100$ cells and 12.02 MAN/100 cells, which significantly decreased compared with control $(P<0.05)$.
\end{abstract}

\section{KEY WORDS}

Hybrid grouper, Dunaliella salina, Iridovirus, megalocityvirus.

Iridovirus contain linear double stranded DNA genom as genetic material (Chinchar et. al., 2005), icosahedral symmetry with 20 -sides capsid that have been infected in a fish, invertebrates and amphibians and identified from more than 20 species of fish in recent years (Hyatt et al., 2000). DNA virus classified as a family Iridoviridae that contains of 5 genera, 3 of them are found in fish (Chinchar et. al., 2005). The complete nukleotide sequence of Iridovirus contains about 90 potential genes and contain of 112,000 base pairs (bp) in length (Kurita, 1998). Iridovirus is a representative of the genus Megalocityvirus. However Megalocityvirus is still a severe causative agent that caused mass mortalities for many spesies in both marine cultured and ornamental fish, mainly in East and South-east Asia (Jeong et. al., 2003, Paperna et al., 2001, Sudthongkong et al., 2002).

Megalocityvirus as an particular contains virusses associated with a range of diseases with clinical sign from skin lesion to systemic infection, darkening of body colouration and lethargy, anemia, petechiae of gills and enlargement of spleen (Inouye, et. al., 1992). The mortality rates varied from low $(0,5-10 \%)$, moderate $(50 \%)$ and death on $24-48$ hours after the onset of sign.

One way to find out the health of fish is to observe the status of macronucleus and micronucleus. The macronucleus is a somatic nucleus (not involved in hereditary information transmission from generation to sexual generation), while the micronuclei is a small additional nucleus that is located outside the main nucleus, one form of cell nucleus due to a faulty division process and formed from an ascent or fragmentary fragment chromosome. The criteria of the observed micronuclei are less than $1 / 3$ in diameter of the nucleus, no contact with the nucleus and the same intensity and absorption of colour. 
Dunaliella salina is one of the microalgae which have the largest beta-carotene content (especially all-trans-ß-carotene and 9- or 9'-cis-ß-carotene) compared to other microalgae, more than $14 \%$ of dry weight (Bhattacharjee, 2016). Carotenoids in Dunaliella salina are a source of Vitamin A and vitamin C of 352,000 IU which can increase the immune system (Talero et al., 2015). Betacaroten have been reported to be immunostimulants in fish (Gourveia et al. 1997, Supamattaya et al. 2005, Raymundo et al. 2005).

Effects of betacaroten on aquatic animals are various: enhance the larval survival and growth (Amar et al. 2004), increase the performance of brood stock (Supamattaya et al. 2005) and larvae (Wyban et al. 1997), increase fish hematological parameters (Nakano et al., 1995) and improve the immune system from various diseases (Amar et al. 2001; Supamattaya et al. 2005).

\section{MATERIALS AND METHODS OF RESEARCH}

Dunaliella salina seedlings used as much as 10 liters with a density of $35 \times 105 \mathrm{cells} / \mathrm{ml}$ which were then cultured in tank on 350 liters of concrete with an initial density of $10 \times 104$ cell/ml. Harvesting was carried out on day 7 with a density of $47 \times 105$ cells $/ \mathrm{ml}$. A total of 350 liters of culture can produce 53.9 grams of dry weight. Furthermore Dunaliella salina is mashed into a powder.

Preparation of Dunaliella Salina Powder. Dunaliella salina is filtered to obtain biomass in the form of paste then are flattened on a tray and dried for about 4 days. The dried paste is smoothed until it changes into powder. A total of 350 liters of Dunaliella salina culture produced 53.9 grams of powder.

Feed Repelletting. The amount of Dunaliella salina powder used is $0 \mathrm{gr}, 2 \mathrm{gr}, 4 \mathrm{gr}$ and $6 \mathrm{gr}$ added in $1 \mathrm{~kg}$ of of refined pellet feed. Then added enough water and adhesive material by $1 \%$ of the total feed. After all components are evenly mixed, the feed are reprinted using molds, and dried using an oven for 2 days at $40^{\circ} \mathrm{C}$ until they are completely dry. Feed is given to the hybrid grouper adlibitum for 10 days.

Iridovirus Isolation. Spleen on hybrid grouper crushed and homogenized using PBS solution with a ratio 1: 5 . Homogenization was carried out by centrifugation at $3.000 \mathrm{rpm}$ for 15 minutes to separate the pellets from the supernatant. The supernatant obtained was filtered and stored in appendorf at a temperature of $-80^{\circ} \mathrm{C}$.

Challange the Iridovirus

The hybrid grouper used is obtained from BBAP Situbodo with weight 4-5 gram. After the hybrid grouper was acclimatized for 7 days and given food containing Dunaliella salina for 10 days, it was soaked in water containing Iridovirus. The dose used is $1 \mathrm{ml}$ of viral isolate for 10 liters of water.

Measurement of erythrocite, hemoglobine, hematocrite, macronuclei and micronuclei. Total erythrocytes measurement follows the steps: blood sample is sucked with a thoma pipette until a scale of 0.5 is then sucked up with a hayem solution to a scale of 101 . After being homogenized for 3-5 minutes, the first drop is then removed and the next drop is inserted into the haemocytometer. The total calculation of erythrocytes was carried out in 5 sightings of the haemocytometer.

Hemoglobin levels can be measured by filling a valid tube with $0.1 \mathrm{~N} \mathrm{HCl}$ up to number 10. Subsequently placed a linear tube between 2 tubes of standard colour. $0.2 \mathrm{ml}$ of fish blood was put into a valid tube, then distilled water and stirred until the colour was exactly the same as the standard colour. Hemoglobin levels are read by looking at the surface of the liquid and matched with numbers on a yellow scale. Hemoglobin levels are expressed in $\mathrm{g} \%$.

Hematocrit levels are expressed as $\%$ of the volume of blood cell solids that can be measured by inserting a blood sample into a microhematocrit tube up to $3 / 4$ of the tube. Then clogged the end of the tube (marked in red) with critoseal. Then centrifuged for 15 minutes at a speed of $12,000 \mathrm{rpm}$. Hematocrit levels can be calculated by the following formula:

Calculation of the number of macronuclei and micronuclei according to Kousar and Javed (2015) is done by placing one drop of blood on the object glass and making a smear. 
After drying, it was rinsed with methanol, stained using $10 \%$ giemsa for 20 minutes and rinsed with distilled water and dried.

\section{RESULTS AND DISCUSSION}

The results of the effect of Dunaliella salina on hybrid grouper were shown in Fig. 1. Based on Figure 1, the mean of erythrocytes at a dose of $6 \mathrm{~g} \mathrm{~kg}^{-1}$ of feed is the highest erythrocytes which is $6,29 \pm 0,017 \mathrm{cells} / \mathrm{mm} 3$ and significantly affected compared to other treatments (P/0.05). The high number of erythrocytes is thought to be because carotenoids in Dunaliella salina can induce limfomyeloid tissue in the kidneys to produce the enzyme erythropoietin so that lymphomyeloid tissue can produce more red blood cells. Carotenoid compounds contained in Dunaliella salina can function as red blood cell enhancers, antioxidants, antibacterials and enhance immunity and substitute for damaged cells (Fretes, et al., 2012). Erythropoietin or EPO is a glycoprotein hormone released by peritubular capillary wall cells in the kidneys and serves to control erythrocyte production (Soldatov, 2005).

The various haematology after treatments of some herbal immunostimulants in fish was reported (Harikrishnan et al. 2003; Alishahi et al. 2010). Nakano et al. (1995) reported that carotenoids-treated increased hematological parameters of fish, dietary carotenoids also influenced blood components. Supplementation of dried algal cells caused retardation of growth in black tiger shrimp (Liao et al. 1993) and striped jack (Watanabe et al. 1990).
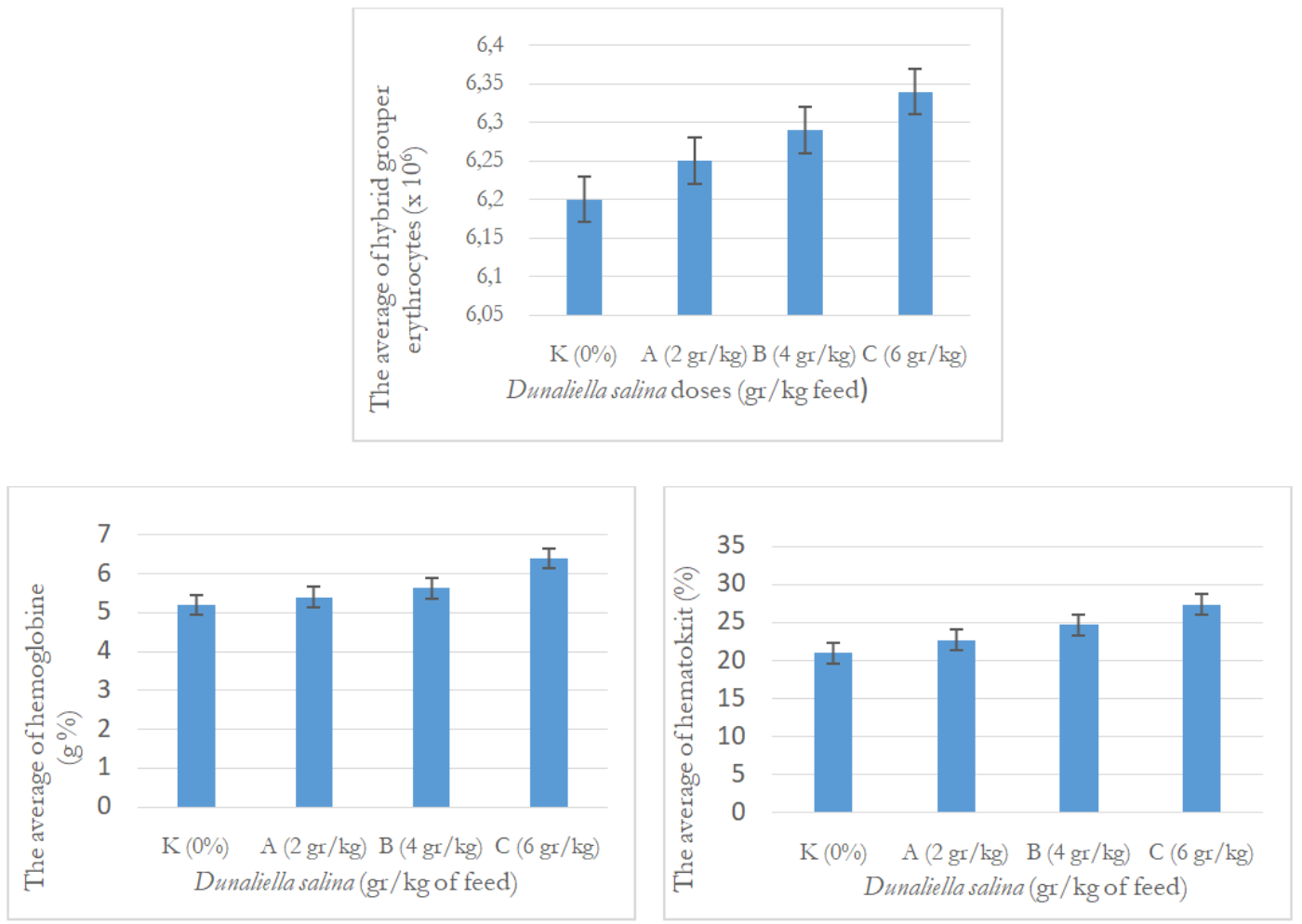

Figure 1 - The average of hybrid grouper erythrocyte, hemoglobine and hematocrite. A, B, and C fish groups fed with 2, 4 and mg kg-1 Dunaliella salina, respectively. $\mathrm{K}$ diet free from Dunaliella salina. Mean \pm SD from 10 fish. Groups with different letter on SD bar were significantly different $(P<0.05)$.

Supplementation of the feed with $6 \mathrm{gr} \mathrm{kg}^{-1}$ Dunaliella Salina for 10 days significantly $(P<0.05)$ increases the erythrocites, $\mathrm{Hb}$ and $\mathrm{HE}$ of Hybrid grouper

The highest hybrid grouper hemoglobin level was also obtained at a dose of $6 \mathrm{~g} \mathrm{~kg}-1$ of feed (Figure 2), which was $6.40 \pm 0,43 \mathrm{~g} \%$ and significantly affected compared to other treatments $(P<0.05)$. The amount of hemoglobin is generally directly proportional to the number of erythrocytes (Lagler, et al., 1977). 
Hematocrit $(\mathrm{HE})$ values and red blood cell counts are general indicators used to determine fish health and describe abnormalities caused by viruses. Hematocrit examination results can also be used as a benchmark to determine fish health. Based on the results of the study, it was found that the highest hematocrit was at a dose of $6 \mathrm{~g} / \mathrm{kg}$ of feed, and significantly affected compared to other treatments $(P<0.05)$. which was $27,33 \pm 0,57 \%$.

After challenging tests with iridovirus, showed hybrid grouper were not given Dunaliella salina had more micronuclei than those given Dunalilella salina. The direct impact due to viral infection is the increase in ROS (Ractive Oxygen Species). In addition to the inate immune system which is an important factor, ROS is also beneficial for hosts, which can limit viral replication. However, ROS that is too high can cause damage to the cells, causing inflammation (Hui-Wem et al., 2017).

The average of micronuclei of hybrid grouper fish after being challenged with Iridovirus ranged between 10.57-14.58 MN/100 cells. Micronuclei is a abnormality in red blood cells that are formed from chromosomal fragments (chromosomal faults) that experience lag in the anaphase phase and fail to divide in cell division (Figure 3a). The disorder is caused by damage to the spindle thread. After arriving at the stage of cell division, the chromosome fragments form a small nucleus called micronuclei. Sayed, et al. (2017) states that if the amount of free radicals is too much, it can cause core DNA damage and spindle thread disfunction.

Based on Figure 2 The dose of $6 \mathrm{~g} / \mathrm{kg}$ of feed is the best treatment with the lowest number of micronuclei compared to other treatments, it was $10,57 \pm 1,09$. In this research, micronuclei significantly decrease in all Dunaliella salina-treated groups $(P<0.05)$. The higher the dose of Dunaliella given, the less the number of micronuclei found. Beta-carotene in Dunaliella salina serves as an antioxidant capable of suppressing free radicals at the onset of macrophage stimulation and avoiding too much ROS.

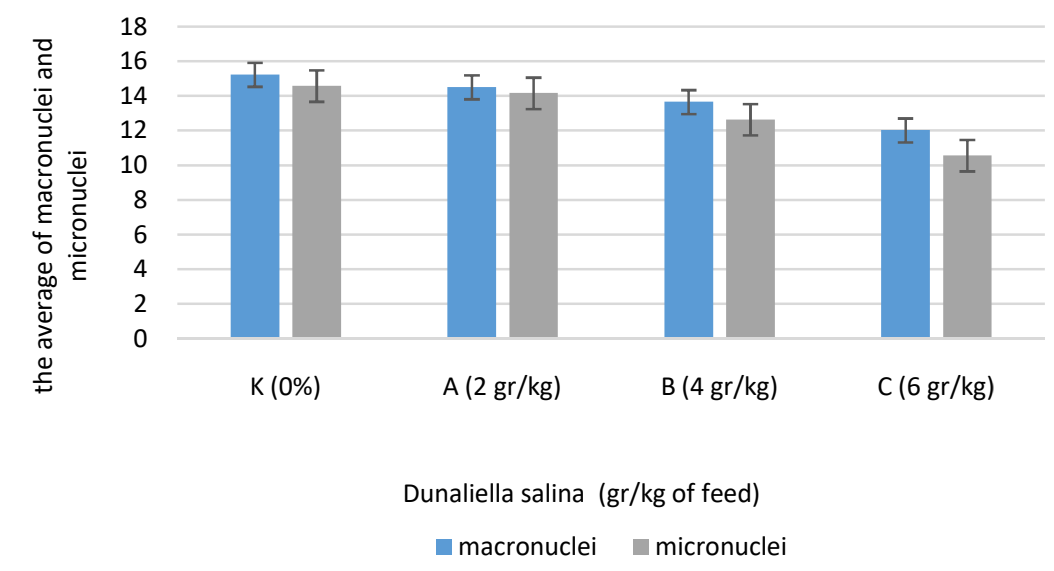

Figure 2 - The average of hybrid grouper macronuclei and micronuclei



(a)



(b)

Figure 3 - Morphology of hybrid grouper macronuclei and micronuclei: (a) micronuclei, (b) macronuclei 
Similar to micronuclei, the highest number of macronuclei in hybrid groupers infected by Iridovirus can be found in fish without Dunaliella salina. The least amount of macronuclei was found in hybrid grouper which was given Dunaliella salina at a dose of $6 \mathrm{~g} \mathrm{~kg}^{-1}$ of feed, which was $12,02 \pm 0,83$ cells, and significantly decrease compared to other treatments $(\mathrm{P}<0.05)$.

The effectiveness of carotenoid source in fish, in terms function of physiological and deposition is species-specific. The same pathways for the metabolism of carotenoids of fish species not possess; therefore, In fish tissues there is no universal transformation of carotenoids (Kop and Durmaz 2008).

\section{CONCLUSION}

Dunaliella salina has an effect on the number erythrocytes, $\mathrm{Hb}, \mathrm{HE}$, macronuclei and micronuclei of hybrid groupers infected by Iridovirus. The use of Dunaliella salina powder as much as $6 \mathrm{~g} \mathrm{~kg}^{-1}$ of feed is the effective dose which can reduce the number of macronuclei and micronuclei. However, the optimal dose and mechanism of Dunaliella salina is still not completely clear, we suggest to do further studies o dose addition and mechanism of Dunaliella salina in as a function of immunostimulant for viruses.

\section{REFERENCES}

1. Alishahi M, Ranjbar M, Ghorbanpor M, Peyghan R, Mesbah M, Razijalali M (2010) Effects of dietary on specific and nonspecific immunity in the common carp Aloe vera (Cyprinus carpi). Int J Vet Res 4:189-195.

2. Amar EC, Kiron V, Satoh S, Watanabe T (2001) Influence of various dietary synthetic carotenoids on bio-defense mechanisms in rainbow trout (Oncorhynchus mykiss). Aquac Res 32:162-173.

3. Amar EC, Kirona V, Satoha S, Watanabea T (2004) Enhancement of innate immunity in rainbow trout (Oncorhynchus mykiss Walbaum) associated with dietary intake of carotenoids from natural products. Fish Shellfish Immunol 16:527-537.

4. Bhattacharjee, M. 2016. Pharmaceutically valuable bioactive compounds of algae. Asian Journal of Pharmaceutical and Clinical Research. 9(6): 43-47.

5. Chincar, V. G. 2008. Family Iridoviridae: Poor Viral Relations No Longer. Department of Microbiology, University of Mississippi Medical Center: USA. $156 \mathrm{hlm}$.

6. Fretes, R.E. and Kemmerling Ulrike. 2012. Mechanism of Trypanosoma cruzi Placenta Invasion and Infection: The Use of Human Chorionic Villi Explants. Journal of Tropical Medicinen Volume 2012: 7 page.

7. Gourveia L, Gomes E, Empis J (1997) Use of Chlorella vulgaris in diets for rainbow trout (Oncorhynchus mykiss) to enhance pigmentation of muscle. Aquaculture 7:61-70.

8. Harikrishnan R, Nisha MR, Balasundaram C (2003) Hematological and biochemical parameters in common carp (Cyprinus carpio) following herbal treatment for Aeromonas hydrophila infection. Aquaculture 221:41-50.

9. Hyatt, A.D., Gould, A.R., Zupanovic, Z., Cunningham, A.A., Hengstberger, S., Whittington, R.J., Kattenbelt, J. and Coupar, B.E.H. 2000. Comparative studies of piscine and amphibian iridoviruses. Arch. Virol., 145:301-331.

10. Inouye, K., Yamano, K., Maeno, Y., Nakajima, K., Matsuoka, S., Wada, Y. and Sorimachi, M. 1992. Iridovirus infection of cultured red sea bream, Pagrus major.Fish Pathol., 27:19-27.

11. Jeong, J. B., Jun, L. J., Yoo, M. H., Kim, M. S., Komisar, J. L. \& Jeong, H. D. (2003). Characterization of the DNA nucleotide sequences in the genome of red sea bream iridoviruses isolated in Korea. Aquaculture 220, 119-133.

12. Lagler, K. F., J. E. Bardach, R. R. Miller and D. R. M. Passino. 1977. Ichthyology. John Willey and Sons, Inc. New York-London. 506 hlm. 
13. Kousar, S and M. Javed. 2015. Studies on induction of nuclear abnormalities in peripheral blood erythrocytes of fish exposed to copper. Turkish Journal of Fisheries and Aquatic Sciences. 15 (1): 8 page.

14. Kop A, Durmaz Y (2008) The effect of synthetic and natural pigments on the colour of the cichlids (Cichlasoma severum sp., Heckel 1840). Aquaculture 16:117-122.

15. Kurita J., Nakajima K., Hirono I. \& Aoki T. (1998). Polymerase chain reaction (PCR) amplification of DNA of red sea bream iridovirus (RSIV). Fish Pathol., 33, 17-23.

16. Liao WL, Nur-E-Borhan S, Okada S, Matsui T, Yamaguchi K (1993) Pigmentation of cultured black tiger prawn by feeding with a Spirulina supplemented diet. 59: 165-169.

17. Nakano T, Tosa M, Takeuchi M (1995) Improvement of biochemical features in fish health by red yeast and synthetic astaxanthin. Agric Food Chem 43:1570-1573.

18. OIE (2012).Red sea bream iridoviral disease. In Manual of Diagnostic Tests for Aquatic Animals 2012, pp. 345-356. Edited by the World Organisation for Animal Health (OIE). Paris: OlE.

19. Paperna, I., Vilenkin, M. \& de Matos, A. P. (2001). Iridovirus infections in farm-reared tropical ornamental fish. Dis Aquat Organ 48, 17-25.

20. Raymundo A, Gouveida L, Batisa AP, Empis J, Sousa L (2005) Fat mimetic capacity of chlorella vulgaris biomass in oilin-water food emulsions stabilized by pea protein. Food Res Int 38:961-965.

21. Sayed, A. E. H., S. Oda and H. Mitani. 2014. Nuclear and cytoplasmic changes in erythrocytes of p53-deficient medaka fish (Oryzias latipes) after exposure to gammaradiation. Mutagen. 1(1): $7 \mathrm{hlm}$.

22. Soldatov, A. A. 2005. Peculiarities of organization and functioning of the fish red blood system. Journal of Evolutionary Biochemistry and Physiology. 41(1): 272-281.

23. Sudthongkong et. al., Miyazaki T., Miyata M. 2002. Iridovirus disease in two ornamental tropical freshwater fishes: African lampeye and Dwarf gourami. Diseases of Aquatic Organisms 48(3):163-73

24. Supamattaya K, Kiriratnikom S, Boonyaratpalin M (2005) Effect of a Dunaliella extract on growth performance, health condition, immune response and disease resistance in black tiger shrimp (Penaeus monodon). Aquaculture 248:207-216.

25. Talero, E., S.Garcia-Maurino., J. Avila-Roman., A. Rodriguez-Luna., A. Alcaide dan V. Motilva. 2015. Bioactive compound isolated from microalga in chronic inflammation and cancer. Marine Drugs. 13: 6152-6209.

26. Watanabe T, Liao w, Takeuchi T, Yamamoto H (1990) Effect of dietary Spirulina supplementation on growth performance and flesh lipids of cultured striped jack. J Tokyo Univ Fish 77:231-239.

27. Wyban J, Martinez G, Sweeney J (1997) Adding paprika to Penaeus vannamei maturation diet improves nauplii quality. World Aquac 28:59-62. 